\title{
New Partnership for Africa's Development and Challenges of Poverty Alleviation in Nigeria
}

\author{
Chilaka Francis Chigozie, Ph.D ${ }^{1}$ and Odoh, Samuel Ituma, Ph.D ${ }^{2}$ \\ ${ }^{I}$ Department of Political Science and Strategic Studies, Federal University Otuoke, Bayelsa State \\ ${ }^{2}$ Department of Political Science Ebonyi State University, Abakiliki, Nigeria
}

\begin{abstract}
The article interrogated NEPAD and challenges of poverty alleviation in Nigeria. It tried to ascertain if the application of neo-liberal framework in the implementation of NEPAD undermine poverty alleviation in Nigeria. Analysis was anchored on the neo-liberal theory and qualitative method of data collection was used to glean data from documentary evidence of secondary sources. Qualitative descriptive analysis was employed with logical induction. The article revealed that at present the NEPAD target on poverty in Nigeria is unlikely to be met. The problem is that market-driven policies avoid analysis of power relations, which ultimately determines inequality and poverty. Again, poverty alleviation using the instrumentality of NEPAD is untenable under a neo-liberal economic framework. On the basis of our findings we recommend that the Nigerian state can only fight the war against poverty if it adopts a welfarist approach or regulated capitalism.
\end{abstract}

Keywords: NEPAD, liberalism, poverty

\section{Introduction}

The poverty situation in Nigeria is galloping (Oshewole, 2011:1). Poverty is deep and pervasive, with about 70 percent of the population living in absolute poverty (Okonjo-Iweala, Soludo and Muhtar, 2003:1). Statistics show that the incidence of poverty using the rate of US \$1 per day increased from 28.1 percent in 1980 to 46.3 percent in 1985 and declined to 42.7 percent in 1992 but increased again to 65.6 percent in 1996. The incidence increased to 69.2 percent in 1997 (CDD, 2014:12). The 2004 Report by the National Planning Commission indicates that poverty has decreased to 54.4 percent. But by 2010 the poverty rate had increased again to 69.1 percent. Nigerian Insight (2014) in its editorial position of February 3, 2014 entitled "The rising rate of poverty in Nigeria" noted that a staggering 112.519 million Nigerians live in relative poverty conditions as revealed by the National Bureau of Statistics (NBS). This figure represents 69 per cent of the country's total population estimated to be 163 million. It noted that it is more worrisome because of the fact that the poverty rate is rising at a time the Gross Domestic Product (GDP) growth rate is put at 7.75 per cent.

The fight against poverty has been a central plank of development planning since independence in 1960 and about fifteen ministries, fourteen specialized agencies, and nineteen donor agencies and non-governmental organizations have been involved in the decades of this crusade but about 70 percent of Nigerians still live in poverty (Soludo,

2003:27). Observers such as Adesopo (2008) and Omotola (2008) have unanimously agreed that successive government's interventions have failed to achieve the objectives for which they were established. The failure to effectively combat the problem has largely been blamed on infrastructural decay, endemic corruption, and poor governance and accountability (Okonjo-Iweala, Soludo and Muhtar, 2003:1).

Some of the interventions are the Directorate of Food, Road and Rural Infrastructure(DFRRI) 1986; National Directorate of Employment (NDE) 1986; Better Life Programme (BLP) 1987; Family upport Programme (FSP) 1994; Family Economic

Advancement Programme (FEAP) 1 997. Others are National Poverty Eradication Programme (NAPEP) 2001 and mostg recently, National Economic Empowerment and Development Strategy (NEEDS) amon

With the recognition of poverty as a common denominator in the global community (see Development Assistance Committee, 2001; Nwaobi, 2003:2), and complementing efforts by poor countries to alleviate poverty, the international community, especially African leaders were not left out in presenting a united front in the fight against poverty.

Hence, the idea of establishing the New Partnership for Africa's Development (NEPAD) to provide a framework for African leaders to alleviate poverty. NEPAD is:

A pledge by African leaders based on a common vision and a firm and shared conviction, that they have a pressing duty to eradicate poverty and to place their countries, both individually and collectively, on a path of sustainable growth and development and, at the same time, to participate actively in the world economy 
and body politic. The Programme is anchored on the determination of Africans to extricate themselves and the continent from the malaise of underdevelopment and exclusion in a globalising world (NEPAD:1).

NEPAD is the result of three parallel initiatives by three groups (individuals). The first is the Millennium Africa Recovery Plan (MAP), led by South African President Thabo Mbeki and unveiled at the World Economic Forum in Davos in January 2001. The second initiative is the Omega Plan, crafted by the President of Senegal, Abdoulaye Wade, and presented to the Summit of Francophone African leaders in Cameroon in January 2001, and the third is, The Compact for African Recovery initiated by the then Executive Secretary of Economic Commission for Africa (ECA) K.Y. Amoako, in response to a mandate provided by African Ministers of Finance in late 2000 (Regional Coordination Mechanism - Africa, 2007).

All three initiatives share a common interest in increasing the pace and impact of Africa's development. While these initiatives share common characteristics, there were also differences reflecting the regional and other biases of the originators. Compromises had to be made in order to merge the three proposals into one initiative. NEPAD thus reflects the compromises involved in arriving at a single initiative.

NEPAD is a road map for accelerated economic growth and sustainable development with a view to eradicating widespread poverty and halting the marginalization of Africa in the globalization process.

The New Partnership for Africa's Development (NEPAD) having been in existence since October 23, 2001, a thorough review of the progress of NEPAD implementation in Nigeria will not be out of place. Therefore the article will attempt a critical examination of NEPAD and challenges of poverty in Nigeria. The article will argue that the application of neo-liberal framework in the implementation of NEPAD has undermined poverty alleviation programmes in Nigeria.

\section{Theoretical Framework}

In this article, analysis will be anchored on the neo-liberal theoretical framework. The theory was developed by Alexander Rustow, Walter Lippman and 23 other scholars at the Walter Lippman Colloquium in August 1938 in Paris, France. The colloquium defined the concept of neoliberalism as the priority of the price mechanism, the free enterprise, the system of competition and a strong and impartial state. Alternatively, neoliberalism might be perceived of as a distinct ideology, descending from, but not identical to liberalism "proper".

The theory was employed to describe an economic philosophy that has become increasingly prominent since the late 1970s which rejects state control and positive government intervention in the economy and focuses instead on free market methods, fewer restrictions on business enterprise and the importance of property rights. Associated with the conservative Right, the theory stresses the shrinking of the state by lowering tax levels, privatizing assets and encouraging and rewarding personal achievement and responsibility. Its adherents oppose environmentalism, fair trade and socialism and labor policies such as collective bargaining rights and the minimum wage. It is usually described as Thatcherism in the United Kingdom and Reaganomics in the United States (http://libguides.usc.edu/content.php?pid=22394\&sid=724915).

The theory is rooted in the orthodox market liberalism as the "the desire to intensify and expand the market, by increasing the number, frequency, repeatability, and formalisation of transactions" (Treanor nd: 5). It is in this propagation of the principle of market transaction to as much areas of social and economic existence and interaction as possible that defines the core value and principle of neoliberalism. This could be spatial or temporal, or terrains of social relationship that would be considered unsuitable to the logic of market transaction.

Bond (2001:4-10) appropriately identifies the basis of contemporary neoliberal globalisation as an attempt to address the crisis of over-accumulation by displacing the crisis. It is in pushing the frontiers of market, as a normative position, that we understand the attempt to resolve that crisis. In its specific manifestation, however, neoliberalism is under-girded by two other core ideas: Monetarism (as the normative framework for regulating macroeconomic affairs), and Supply-side Economics (as the framework for addressing firm level production activities).

The specific configuration of the expansion and intensification of market logic and norms, monetarism and supply-side management, and manifestation in actual policy practice and implementation, will, however, depend on the configuration of social forces and agencies that contest the policy terrain.

The approach centered on the words of Reagan: "A big government that promises you everything is a big government that will take everything from you". Seemingly triumph of neo-liberalism especially with the collapse of the Soviet Union and ascendancy of the US as the hegemon has drawn dissenting voices to market ideology.

The emergency of neoliberalism led to fundamentally reconfiguring of the roles and responsibility of states, markets, individuals, families and groups. Generally, neoliberalism has transferred decision-making power away from the public sphere of the state and civil/society to the private sphere of the market. While 
neoliberal rhetoric has emphasized expanding and enriching individual choice, neoliberal practice has constrained choice by imposing market criteria on all social exchanges.

Neoliberalism generally includes the belief that freely adopted market mechanisms is the optimal way of organising all exchanges of goods and services. Free markets and free trade will, it is believed, set free the creative potential and the entrepreneurial spirit which is built into the spontaneous order of any human society, and thereby lead to more individual liberty and well-being, and a more efficient allocation of resources (Hayek, 1973; \& Rothbard, 2004). The general neoliberal vision is that every human being is an entrepreneur managing their own life, and should act as such. Hence, if everyone lives by such entrepreneurial precepts, then a world will come into existence in which not just goods and services, but all human and social life, is the product of conformity to market forces. More than traditional market liberals, neoliberals therefore have a heroic attitude to the entrepreneur (http://web.inter.nl.net/users/Paul.Treanor/neoliberalism.html).

Neoliberalism advocates the use of international organisations like World Bank, International Monetary Fund, United Nations and its associated agencies like World Trade Organization, among others to advance the interest of the market and other developmental blueprints. In the NEPAD document, African leaders were implored to work with the World Bank, the International Monetary Fund (IMF) and the United Nations (UN) agencies to accelerate implementation and adoption of the Comprehensive Development Framework, the Poverty Reduction Strategy and related approaches. Again, the document had the objective that African leaders should support existing poverty reduction initiatives at the multilateral level, such as the Comprehensive Development Framework of the World Bank and the Poverty Reduction Strategy approach linked to the debt relief initiative for Highly Indebted Poor Countries (HIPCs)(see NEPAD, 2001:29)

The analytical significance of this theory to our article is clear because it touches at the heart of some of the issues raised in the NEPAD document as basis to accelerate development and poverty alleviation in Africa and Nigeria in particular.

\section{Past Efforts to Alleviate Poverty in Nigeria}

There have been attempts in the past within the country and the continent to arrest the incidence of poverty such as Operation Feed the Nation (OFN), Free and Compulsory Primary Education (FCPE), Green Revolution, Low Cost Housing, River Basin Development Authorities (RBDA), National Agricultural Land Development Authority (NALDA), Agricultural Development Programme (ADP), Agricultural Credit Guarantee Scheme (ACGS), Strategic Grains Reserves Programme (SGRP), Rural Electrification Scheme (RES) and Rural Banking Programme (RBP) within the country. At the continental level, anti-poverty frameworks and plans and programmes such as: The Lome Convention (1975-1990s), the Lagos plan of Action (1980), the African Alternative Framework to SAP for Socio-Economic Recovery and Transformation ( 1989).

The Obasanjo Administration which set up the Joda Panel, to review the various poverty eradication programmers of the previous regimes, identified over twenty such programmes/institutions. Some of them are:

i. The National Directorate of Employment (NDE)

ii. Peoples Bank of Nigeria (PBN)

iii. Nigerian Agricultural and Cooperative Bank Ltd (NACB)

iv. Nigerian Agricultural Insurance Corporation (NAIC)

v. National Commission for Nomadic Education (NCNE)

vi. National Primary Health Care Development Agency (NPHCDA)

vii. National Agricultural Land Development Authority (NALDA)

viii. National Commission for Mass Literacy, Adult and Non-Formal Education

ix. Federal Agricultural Coordinating Unit (FACU)

x. Directorate for Foods, Roads and Rural Infrastructures (DFFRI)

xi. Agricultural Projects Monitoring and Evaluation Unit (APMEU)

xii. Family Economic Advancement Programme (FEAP)

xiii. Industrial Development Centre (IDC)

xiv. Federal Department of Rural Development (FDRD)

xv. Federal Ministries of Agriculture, Water Resources and Power and Steel

xvi. River Basin Development Authorities (RBDAs)

xvii. Family Support Trust Fund (FSTF)

xviii. National Centre for Women Development (CWD)

xix. Nigerian Bank for Commerce and Industry (NBCI)

xx. Nigerian Industrial Development Bank (NIDB)

xxi. Nigerian Export-Import Bank

xxii. National Economic Reconstruction Fund (NERFUND) 
NEPAD is one of the latest efforts in this direction with the aim of accelerating economic growth and sustainable development with a view to eradicating widespread poverty and halting the marginalization of Africa in the globalization process. Not unexpected, scholars such as Aluko (2001)) have tried to interrogate NEPAD vis-à-vis its intended goal.

Aluko (2001) states that the real but unexpressed reason NEPAD was embraced and acceptable to the donor-nations is that it's not entirely the product of Africa, rather, it was initiated by Prrsident Mbeki of South Africa as a direct response to a suggestion and demand by the British Prime Minister, Tony Blair. Blair had indicated that he would want to see a comprehensive development scheme for Africa, but stressed that the scheme be developed by Africans "themselves". Nyongo et al (2002:36) remarked that the objectives of NEPAD are for the African canoe to be firmly tied to the North's neo-liberal ship on the waters of globalization.

Ikome (2006) argued that the shift from the Lagos Plan of Action (LPA) to the NEPAD has been dictated by changes in global realities and circumstances. He argues that individual African governments' concern with vulnerability nationally has been responsible for the low levels of implementation of regional economic initiatives. In this regard, the prospects for the sustained implementation of regional cooperation initiatives is structured by expectations of socio- economic benefits, the cost of compliance to states and the institutions to enforce compliance. According to the NEPAD (2001) NEPAD'S primary objectives are four-fold. It aims to eradicate poverty, to promote sustainable growth and development, to integrate Africa in the world economy and accelerate the empowerment of women. NEPAD represents, as Joseph (2002) suggests, a new wave of recovery and renewal for Africa.

Many scholars such as Bond (2002) and Taylor (2005) have looked at NEPAD'S predecessors and the events leading up to NEPAD (both in terms of years and decades) in greater depth hence it is not our intention to construct a teleological, step by step series of events culminating in NEPAD. However, our goal is to show that the application of neo-liberal framework in the implementation of NEPAD has undermined poverty alleviation programmes in Nigeria. The logical data framework below shows the methodological viability of this article.

Table 1: Logical Data Framework

\begin{tabular}{|c|c|c|c|c|c|}
\hline $\begin{array}{ll}\text { What } & \text { to } \\
\text { investigate } & \\
\end{array}$ & Variables & Main Indicators & Data Sources & $\begin{array}{l}\text { Method of Data } \\
\text { Collection }\end{array}$ & $\begin{array}{ll}\text { Method of } \\
\text { Analysis }\end{array}$ \\
\hline \multirow[t]{2}{*}{$\begin{array}{l}\text { The application of } \\
\text { neo-liberal } \\
\text { framework in the } \\
\text { implementation of } \\
\text { NEPAD } \\
\text { undermined } \\
\text { poverty alleviation } \\
\text { programmes in } \\
\text { Nigeria between } \\
2000 \text { and } 2014\end{array}$} & $\begin{array}{l}\text { (X) } \\
\text { The application of } \\
\text { neo-liberal } \\
\text { framework in the } \\
\text { implementation of } \\
\text { NEPAD }\end{array}$ & $\begin{array}{l}\text { - The } \\
\text { recommendation by NEPAD } \\
\text { document that African leaders } \\
\text { should work with the World } \\
\text { Bank, the International } \\
\text { Monetary Fund (IMF) and the } \\
\text { United Nations (UN) agencies } \\
\text { to accelerate implementation } \\
\text { and adoption of the } \\
\text { Comprehensive Development } \\
\text { Framework, the Poverty } \\
\text { Reduction Strategy and } \\
\text { related approaches } \\
\text { - The objective that } \\
\text { African leaders should } \\
\text { support existing poverty } \\
\text { reduction initiatives at the } \\
\text { multilateral level, such as the } \\
\text { Comprehensive Development } \\
\text { Framework of the World } \\
\text { Bank and the Poverty } \\
\text { Reduction Strategy approach } \\
\text { linked to the debt relief } \\
\text { initiative for Highly Indebted } \\
\text { Poor Countries (HIPCs)(see } \\
\text { NEPAD, 2001:29). } \\
\text { - }\end{array}$ & $\begin{array}{l}\text { Text } \\
\text { books and journal } \\
\text { publications; } \\
\text { rence proceeding } \\
\text { et sources Intern } \\
\text { al documents }\end{array}$ & $\begin{array}{l}\text { Qualitative } \\
\text { method of } \\
\text { secondary sources } \\
\text { of data }\end{array}$ & $\begin{array}{l}\text { Neo-liberal } \\
\text { theory; } \\
\text { qualitative } \\
\text { descriptive } \\
\text { analysis; } \\
\text { inductive } \\
\text { and logical } \\
\text { inference }\end{array}$ \\
\hline & $\begin{array}{l}\text { (Y) } \\
\text { The undermining } \\
\text { of poverty } \\
\text { alleviation } \\
\text { programmes in } \\
\text { Nigeria between } \\
2000 \text { and } 2014\end{array}$ & $\begin{array}{l}\text { - Poor education, } \\
\text { health and poverty indicators } \\
\text { in Nigeria. For instance, } \\
\text { Nigeria is suppose to reduce } \\
\text { poverty to } 21 \% \text { to achieve } \\
\text { MDG target by } 2015 \text {, but } \\
\text { current poverty rate stands at } \\
62.6 \% \text { Absolute poverty } \\
\text { rate in Nigeria is } 99.284\end{array}$ & $\begin{array}{l}\text { Text } \\
\text { books and journal } \\
\text { publications; } \\
\text { rence proceeding } \\
\text { al sources Intern } \\
\text { al documents }\end{array}$ & $\begin{array}{l}\text { Qualitative } \\
\text { method of } \\
\text { secondary sources } \\
\text { of data }\end{array}$ & $\begin{array}{l}\text { Neo-liberal } \\
\text { theory; } \\
\text { qualitative } \\
\text { descriptive } \\
\text { analysis; } \\
\text { inductive } \\
\text { and logical } \\
\text { inference }\end{array}$ \\
\hline
\end{tabular}




\begin{tabular}{|l|l|l|l|}
\hline & $\begin{array}{l}\text { million or } 60.9 \text { per cent; the } \\
\text { dollar per day measure puts } \\
\text { the rate at 61.2 per cent; and } \\
\text { the subjective poverty } \\
\text { measure puts it at 93.9 per } \\
\text { cent. Income inequality } \\
- \text { has risen from 0.429 in 2004 } \\
\text { to 0.447 in 2010 (see } \\
\text { Nigerian Insight, February 3, } \\
2014 \text { also available at: } \\
\text { http:/nigerianinsight.com/risi } \\
\text { ng-rate-poverty-nigeria/). }\end{array}$ & \\
\hline
\end{tabular}

Source: designed by the author

\section{NEPAD, Neo-Liberal Framework and Poverty Alleviation Programmes in Nigeria.}

Let us first establish that NEPAD is anchored on neo-liberal framework before establishing how it has undermined poverty alleviation programmes in Nigeria. As stated in the NEPAD document, the African "Strategy for Achieving Sustainable Development in the 21st Century," has the following structure:

\section{A. Conditions for Sustainable Development}

A1. Peace, Security, Democracy and Political governance

A2. Economic and Corporate Governance

A3. Sub-regional and Regional Approaches to Development

\section{B. Sectoral Priorities}

B1. Infrastructure

B2. Human Resource Development

B3. Agriculture

B4. Environment

B5. Culture

B6. Science and Technology Platforms

\section{Mobilizing Resources}

C1. Capital Flows

C2. Market Access (see NEPAD document, 2001).

Under Sectoral Priorities, Human Resource Development, for example, is further divided into three sub initiatives: Poverty Reduction, Education, Reversing the Brain Drain, and Health. The actions under Poverty Reduction are stated as follows:

$\square \square$ Require that country plans prepared for initiatives in this programme of actionassess their poverty reduction impact, both before and after implementation.

$\square \square$ Work with the World Bank, the International Monetary Fund (IMF) and theUnited Nations (UN) agencies to accelerate implementation and adoption of the Comprehensive Development Framework, the Poverty Reduction Strategy and related approaches.

Consider, for example, the stipulation that African leaders "work with the World Bank, the International Monetary Fund (IMF) and the United Nations (UN) agencies to accelerate implementation and adoption of the Comprehensive Development Framework, the Poverty Reduction Strategy and related approaches".

Again, the last objective under poverty reduction as contained in NEPAD documents reads as follows:

To support existing poverty reduction initiatives at the multilateral level, such as the Comprehensive Development Framework of the World Bank and the Poverty Reduction Strategy approach linked to the debt relief initiative for Highly Indebted Poor Countries (HIPCs) (see NEPAD, 2001:29).

The question is why must African leaders work with World Bank, IMF and other United Nations agencies? It is axiomatic that the World Bank and IMF are drivers of neo-liberalism, and may not change in the foreseeable future. Hence the idea of reducing poverty as contained in the NEPAD document is rooted in postWashington Consensus. In the magazine, African Today, August, 2001, we understood that the real but unexpressed reason why NEPAD became acceptable to the G-8 is that it is not entirely the product of an African initiative as claimed. Here, NEPAD was in fact, initiated by Thabo Mbeki as a direct response to a suggestion and demand by the former British Prime Minister, Tony Blair, who had earlier indicated that he would want to see a comprehensive development scheme for Africa to feature in his second term as Prime Minister, but would like the scheme to be developed by Africans "themselves". 
Some of the tenets of neo-liberalism are Marketisation, deregulation, privatisation, political dominance exercised through the formation of class-based alliances; construction of autonomous, responsibilized, entrepreneurial capitalist subjects among others. There is no doubt that these tenets of neo-liberalism have retarded development in Africa and Nigeria in particular. While some of the tenets of neo-liberalism have changed, the adverse impact on African economies remains the same.

For instance, Adesina (2002:5) argues that:

While there has been significant shift in the language of deploying the neoliberal policy instruments, from the early days of orthodox stabilisation and liberalisation agenda and the current so-called post-Washington Consensus, the core values remain the same

Hence, Olukoshi (2003:26) argues that the treatment of history is especially prevalent in current analyses of NEPAD. To him:

The essentially neo-liberal framework that informs the economic principles and direction spelt out in the NEPAD document represents a set back in the African quest for a return to the path of sustained economic growth and development (Olukoshi 2003: 26).

From the foregoing analysis, we can begin to see the likely adverse impact of neo-liberal framework on poverty reduction in Nigeria.

NEPAD like other previous poverty alleviation efforts in Nigeria have been pursued through the application of orthodox capitalist strategies. For instance, the first three National Development Plans indirectly attempted to deal with poverty reduction through the pursuit of economic growth. The fourth development plan attempted to curtail the level of poverty through, "The increase in the real income of the average citizen, even distribution of income among individuals and socio-economic groups" (Aniekan, 2011:186).

The regime of Obasanjo from 1999-2007 had introduced the new economic reform program, National Economic Empowerment Strategy (NEEDS) in 2004. This strategy is currently implemented in Nigeria under President Goodluck Jonathan. However, this policy is not too different from the IMF-WB sponsored Structural Adjustment Program. This is because virtually all the elements of SAP, namely privatization, deregulation etc, are embedded in the new program (Ekpo, 2004). Like SAP before it, not much is expected of NEEDS because of its capitalist heritage.

NEAPD is not different. Let us consider poverty trends in Nigeria since NEPAD came into being. The 2004 report by the National Planning Commission indicates that poverty in Nigeria decreased to 54.4 percent. But by 2010, the poverty rate had increased to 69.1 percent (see CDD, 2014:12). The country ranks very low in socio-economic and development indices. In its Human Development Report for 2011, the UNDP ranked Nigeria at 156 out of 187 countries.

Table 2: showing the incidence of poverty by geopolitical zones between 1980 to 2010

\begin{tabular}{|l|l|l|l|l|l|l|}
\hline Geo-political Zones & \multicolumn{5}{l|}{ Percentage } \\
\hline Year & 1980 & $1985 / 86$ & 1992 & 1997 & 2004 & 2010 \\
\hline North West & 37.7 & 48.4 & 36.5 & 62.0 & 71.2 & 77.7 \\
\hline North Central & 32.2 & 48.4 & 46.0 & 53.0 & 67.0 & 67.5 \\
\hline South East & 12.9 & 30.9 & 41.0 & 79.5 & 26.7 & 67.0 \\
\hline South West & 13.4 & 42.0 & 43.1 & 74.1 & 43.0 & 59.1 \\
\hline South-South & 13.2 & 38.0 & 40.8 & 78.6 & 35.1 & 63.7 \\
\hline North East & 35.6 & 53.2 & 54.0 & 68.0 & 72.2 & 76.3 \\
\hline Nationwide & 28.1 & 43.0 & 42.7 & 69.2 & 54.4 & 69.0 \\
\hline
\end{tabular}

Source: Center for Democracy and Development (CDD) (2014:13).

Nigeria is unlikely to meet the Millennuium Development Goals in 2015. For Nigeria to attain target one of the MDG, poverty is supposed to be reduced from $42 \%$ in 1999 to $21 \%$ in 2015 . But by 2010 , poverty has increased to $69 \%$ as shown in the table below.

Table 3: showing Poverty Trends in Nigeria

\begin{tabular}{|c|c|c|c|}
\hline Year & Poverty level (\%) & $\begin{array}{ll}\text { Estimated } & \text { Total } \\
\text { population }(m) & \end{array}$ & Population in poverty \\
\hline 1980 & 27.2 & $65.0 \mathrm{~m}$ & $17.7 \mathrm{~m}$ \\
\hline 1985 & 46.3 & $75.0 \mathrm{~m}$ & $34.7 \mathrm{~m}$ \\
\hline 1992 & 42.7 & $91.5 \mathrm{~m}$ & $39.3 \mathrm{~m}$ \\
\hline 1996 & 65.6 & $102.3 \mathrm{~m}$ & $67.1 \mathrm{~m}$ \\
\hline 2004 & 54.4 & $126.3 \mathrm{~m}$ & $68.1 \mathrm{~m}$ \\
\hline 2010 & 69 & 167 & 112.5 \\
\hline
\end{tabular}

Source: National Bureau of Statistics, cited in CDD (2014:15)

Currently, Nigeria's poverty rate stands at $62.6 \%$ (source,

http://www.ng.undp.org/content/nigeria/en/home/library.html), while she is expected to halve poverty to $21 \%$ by 2015, to meet up with the MDG target. At present the MDG target on poverty in Nigeria is unlikely to be met. In fact, a grim statistics of the population of Nigerians in abject poverty was released on June 12, 2013 by the 
National Bureau of Statistics which said that about 112million Nigerians live below the poverty line. This followed another depressing disclosure by the World Bank, which also said that the population of Nigerians in poverty has increased considerably.

The figure represents about 67 per cent of the entire population.

The report, made available to the Nigeria Politics Online today, stated:

On the aggregate basis, the economy when measured by the Real Gross Domestic Product, grew by 7.68 per cent in the fourth quarter of 2011, as against 8.60 per cent in the corresponding period of 2010 . The 0.92 percentage point decrease in Real GDP growth observed in the fourth quarter of 2011 was a result of production shut-down in the oil sector during the period. (Nigerian Politics Online, 2013, Available athttp://nigeriapoliticsonline.com/poverty-has-increased-considerably-in-nigeria-world-bank-as-bureau-ofstatistics-confirms-112-million-nigerians-living-below-poverty-line/).

The World Bank in its "May 2013 Nigeria Economic Report" said the number of Nigerians living in poverty was increasing too rapidly.

\section{The reported noted:}

Poverty rates remain high in Nigeria, particularly in rural areas. These rates declined between 20032004 and 2009- 2010, although not nearly as fast as would be expected from the pace of economic growth in the country. While the officially reported growth rates of GDP well exceed population growth in the country, the pace of poverty reduction does not; this implies that the number of poor Nigerians living below the poverty line has grown measurably (Nigerian Politics Online, 2013, Available athttp://nigeriapoliticsonline.com/poverty-hasincreased-considerably-in-nigeria-world-bank-as-bureau-of-statistics-confirms-112-million-nigerians-livingbelow-poverty-line/)

Again, the Nigerian Insight, in its editorial position of February 3, 2014 entitled "The rising rate of poverty in Nigeria" noted that a staggering 112.519 million Nigerians live in relative poverty conditions as revealed by the National Bureau of Statistics (NBS). This figure represents 69 per cent of the country's total population estimated to be 163 million. It noted that it is more worrisome because of the fact that the poverty rate is rising at a time the Gross Domestic Product (GDP) growth rate is put at 7.75 per cent.

In a 26-page report, "The Nigeria Poverty Profile 2010," released, in Abuja, by the Statistician-General of the NBS, Dr. Yemi Kale, noted that the figure might increase to 71.5 per cent when the 2011 figure is computed, especially if the potential impacts of several anti-poverty and employment generation intervention programmes are not factored in. The 2010 figure, the report said, was arrived at based on a survey of randomly selected 20 million households with an average of between four to six family members using the relative poverty measurement.

According to the statistician, this measurement compares the living standards of people living in a given society within a specified period of time. Also, other poverty measurement standards used in measuring poverty by the NBS such as absolute measure, the dollar per day measure and the subjective poverty measure, show that the poverty level is on the increase. For instance, absolute measure puts the country's poverty rate at 99.284 million or 60.9 per cent; the dollar per day measure puts the rate at 61.2 per cent; and the subjective poverty measure puts it at 93.9 per cent. The report, which provides details of poverty and income distribution across the country, put the 2004 poverty measurement rate at 54.4 per cent. It also shows that income inequality had risen from 0.429 in 2004 to 0.447 in 2010 . The highlight of the report shows that the North-West and the North-East had the highest poverty rates in the country in 2010 with 77.7 per cent and 76.3 per cent respectively. However, the South-West geo-political zone recorded the lowest at 59.1 per cent (see Nigerian Insight, February 3, 2014; also available at: http://nigerianinsight.com/rising-rate-poverty-nigeria/).

Of all the 36 states of the federation, Sokoto had the highest poverty rate ( 86.4 per cent), while Niger had the lowest at (43.6 per cent). The 2004 poverty rate showed that Jigawa State had the highest rate of 95 per cent while Anambra, with a poverty rate of 22 per cent, was the least poverty-stricken state (Nigerian Insight, February 3, 2014; also available at: http://nigerianinsight.com/rising-rate-poverty-nigeria/).

The problem is that market-driven policies avoid analysis of power relations, which ultimately determines inequality and poverty. It is strongly contended that the most crucial factor that accounts for the persistence of low levels of living, rising unemployment, and growing income inequality in the Third World is the highly asymmetrical distribution of economic and political power between the rich and poor countries. This makes the rich nations to not only control the pattern of international trade but also to dictate the terms whereby technology, foreign aid, and private capital are transferred to developing countries. Given the highly unequal distribution of world resources between the North and the South, it is not surprising that the economies of the latter cannot be resilience and self-reliant. Under this situation poverty alleviation is untenable and cannot be sustained.

According Aniekan (2011:187) in Nigeria, many workers lost their employment due to the adoption of capital intensive method of production in some sectors of the economy. Many were also laid-off due to the 
rationalization exercise that was adopted during the SAP years. Again, the structural adjustment program which was implemented in Nigeria from 1986 worsened the incidence of poverty in the country. According to Obadan (1997), it accentuated socio-economic problems of income inequality and led to unequal access to food, shelter, education, health, and other essentials of life. This was so due to some of the conditionalities which were spelt out to Nigeria by IMF and World Bank. Some of them included review of public expenditure, removal of subsidies and reduction of grants, as well as subventions and loans to parastatals. With complete government's deregulation of the economy, virtually all social services, education, health, and infrastructural facilities, declined irredeemably. This supports the thesis that capitalist economy, instead of alleviating poverty, rather intensifies its magnitude and complexity.

Another problem with liberalsim vis-à-vis poverty eradication is that, it tends to destroy the social structure and cohesion of the society thus making it impossible for communal effort and local net-works for local enterprises to thrive. The faith in free markets, exhibited by NEPAD ignores the fact that no highly industrialised nation ever got to the economic position it is in now by adopting free-market policies (Chang, 2002).

On the basis of our findings, we validate our hypothesis which states that the application of neo-liberal framework in the implementation of NEPAD has undermined poverty alleviation programmes in Nigeria.

\section{Conclusion}

The central argument of this article is that poverty alleviation using the instrumentality of NEPAD is untenable under a neo-liberal economic framework. The article showed that poverty level in Nigeria has increased instead of reducing as could be glanced from the empirical evidence drawn from data used in the article. The situation has remained regardless of past government's efforts which were aimed toward alleviating poverty. Some of these efforts are, Operation Feed the Nation (OFN), the Green Revolution (GR) National Directorate for Employment (NDE), National Poverty Eradication Programme (NAPEP), National Economic Empowerment Development Strategy (NEEDS) and lately NEPAD. From some of the works reviewed it is contended that failure to alleviate the poverty is attributed to poor policy formulation and the non involvement of the poor in the implementation process.

This article dismissed the above arguments as being devoid of empirical accuracy. It rather argued that poverty alleviation is untenable under a neo-liberal/capitalist economic framework. In addition, the inherent contradictions of neo-liberalism were highlighted. These include appropriation, and accumulation of capital and the impoverishment of the working class. These vices rather than alleviate poverty exacerbates it. On the basis of our findings we recommend that the Nigerian state can only fight the war against poverty if it adopts a welfarist approach or regulated capitalism.

\section{References}

[1.] Adesina, J. (2002) "Neoliberalism, Labour and the Dilemma of Democracy: the Nigerian Case." Paper Presented at the CASS/OSIWA Conference on Democracy in Nigeria: the journey so far. 18-20 February. Abuja, Nigeria

[2.] Aniekan, E.E. (2011) "Poverty Alleviation in Nigeria Through Capitalism Economic Framework". Journal of Sustainable Development in Africa, Vol. 13. No. 2. pp. 181-191

[3.] Bond, P. (2001) Against Global Apartheid: South Africa meets the World Bank, IMF and International Finance. Cape Town: UCT Press.

[4.] Bond, P. (2002) Fanon's Warning: a Civil Society Reader on the New Partnership for Africa's Development. Trenton, NJ: Africa World Press.

[5.] Center for Democracy and Development (2014) The Millennium Development Goals: Progress, Prospects and Policy Implications. Abuja:CDD

[6.] Chang, H.J. (2002) Kicking Away the Ladder: Development strategy in Historical Perspective. London: Anthem Press.

[7.] Civil Society Indaba (2002) Resolution on the New Partnership for Africa's Development, adopted in Johannesburg, May

[8.] Development Assistance Committee (DAC) (2001) "Rising to the Global Challenge: Partnership for Reducing World Poverty". Policy Statement by the DAC High Level Meeting upon Endorsement of the DAC Guidelines on Poverty Reduction. Paris, 26-28 April.

[9.] Ekpo, A.H. (2004) The Economics of Structural Adjustment and Adjustment of Economics. $9{ }^{\text {th }}$ Inaugural Lecture Delivered at the University of Uyo, Nigeria

[10.] Ikome, Francis N. (2006) "From the Lagos Plan of Action (LPA) to the New Partnership for Africa's Development (NEPAD): The Political Economy of African Regional Initiatives" Available at: http://wiredspace.wits.ac.za/handle/10539/196 (Assessed, 25th July, 2014).

[11.] NEPAD (2001) "The New Partnership for Africa's Development". Available at: http://www.nepad.org/2005/files/documents/inbrief.pdf (Accessed 23 May 2014).

[12.] NEPAD Secretariat (2001) The New Partnership for Africa's Development (NEPAD). Abuja.

[13.] Nigerian Insight (2014) "The rising rate of poverty in Nigeria" February 3. Available at: http://nigerianinsight.com/rising-ratepoverty-nigeria/ (Accessed 23 May 2014).

[14.] Nigerian Politics Online (2013) "Poverty has increased considerably in Nigeria -World Bank ...As Bureau of Statistics confirms 112 million Nigerians living below poverty line" Available at: http://nigeriapoliticsonline.com/poverty-has-increased-considerablyin-nigeria-world-bank-as-bureau-of-statistics-confirms-112-million-nigerians-living-below-poverty-line/(Assessed, 25th July, 2014). 
[15.] Nwaobi, G. C. (2003) Solving the Poverty Crisis in Nigeria: An Applied General Equilibrium Approach. Abuja, Gwagwalada: Quantitative Economic Research Bureau.

[16.] Obadan, M. (1997) Analytical Framework for Poverty Reduction: Issues of Economic Growth versus other Strategies in Poverty Alleviation in Nigeria: Non Poor, Core Poor. Ibadan: Pat May Press Ltd.

[17.] Obi, C. (2002) "Reconstructing Africa's Development in the New Millennium through NEPAD: Can African Leaders Deliver the Goods?" Paper presented at the 10th General Assembly of CODESRIA on the theme: 'Africa in the New Millennium' Nile International Conference Centre, Kampala, Uganda, 8-12 December

[18.] Okonjo-Iweala, N. Soludo, C. C., Muhtar, M. (2003) “Introduction”, in N. Okonjo-Iweala, C. C. Soludo, M. Muhtar (eds.) The Debt Trap in Nigeria: Towards a Sustainable Debt Strategy. Trenton: Africa World Press, Inc.

[19.] Olukoshi, A. (2002) "Governing the African Political Space for Sustainable Development: a reflection on NEPAD." Paper prepared for the African Forum for Envisioning Africa. Nairobi, Kenya 26-29 April 2002.

[20.] Omotola, J .S. (2008) "Combating Poverty for Sustainable Human Development in Nigeria: The Continuing Struggle". Journal of Poverty, 12(4): 496-517.

[21.] Oshewolo, S. (2010) "Galloping Poverty in Nigeria: An Appraisal of the Government's Interventionist Policies". Journal of Sustainable Development in Africa 12(6): 264-274.

[22.] Oshewolo, S. (2011) "Poverty Reduction and the Attainment of the MDGS in Nigeria: Problems and Prospects". International Journal of Politics and Good Governance Vol.2, No. 2.3. Pp. 1-22

[23.] Regional Coordination Mechanism-Africa (2007) Challenges and Prospects in the Implementation of NEPAD. A Publication of the RCM-Africa Secretariat.

[24.] Rodrik, D. (2003) "Institutions, Integration, and Geography: In search of the deep determinants of economic growth". In D. Rodrik (ed.) In Search of Prosperity: Analytic Country Studies on Growth. Princeton, NJ: Princeton University Press.

[25.] Soludo, C. C. (2003) "Debt, Poverty and Inequality: Toward an Exit Strategy for Nigeria and Africa", in N. Okonjo-Iweala, C. C. Soludo, and M. Muhtar (eds.) The Debt Trap in Nigeria: Towards a Sustainable Debt Strategy. Trenton: Africa World Press, Inc.

[26.] Taylor, I. (2005) NEPAD: Towards Africa's Development or Another False Start? London: Zed Books

[27.] Treanor, Paul. (n.d.) "Neoliberalism: origins, theory and definition". Available at: http://web.inter.nl.net/users/Paul.Treanor/neoliberalism.html. (Accessed 22 July, 2014). 